\title{
Nutritional Effect of Boiled and Baked Soybean Dockounou on the Wistar Rats Health Conditions
}

\author{
Kouadio N. Joseph, Kra K. A. Sevérin*, Niamké L. Sébastien \\ Laboratory of Biotechnologies, UFR Biosciences, Felix Houphouet Boigny University, Côte d'Ivoire
}

Copyright $\bigcirc 2017$ by authors, all rights reserved. Authors agree that this article remains permanently open access under the terms of the Creative Commons Attribution License 4.0 International License

\begin{abstract}
This study was to assess the physiological impact of boiled and baked soybean Dockounou on Wistar rats wealthy after feed them with these diets. For this, 15 strains Wistar rats aged $50 \pm 3$ days and with average weight between 55 and $60 \mathrm{~g}$ were fed with different diets. Biochemical parameters of their serum and weight of organs (liver and kidney) were performed at the end of experiment. The glycemia content registered in serum was $0.74 \pm 0.13 \mathrm{~g} / \mathrm{L}$ and $0.74 \pm 0.11 \mathrm{~g} / \mathrm{L}$ for boiled and baked soybean Dockounou, respectively. That of cholesterol was $0.91 \pm 0.16 \mathrm{~g} / \mathrm{L}$ and 0.86 $\pm 0.15 \mathrm{~g} / \mathrm{L}$ and HDL was $0.65 \pm 0.069 \mathrm{~g} / \mathrm{L}$ and $0.62 \pm 0.05 \mathrm{~g} / \mathrm{L}$ for the same diets respectively. Any pathological, dysfunction and physiological abnormalities were not identified as far as concern rat's serum and organs. Thereby, any significant difference at 5\% level was registered between the control diet results and those of soybean Dockounou. Thus, the consumption of boiled and baked Dockounou is benefit for Wistar rats' health and also these feed can be advised as a good diet for their use in laboratory.
\end{abstract}

Keywords Soybean Dockounou, Boiled Soybean Dockounou, Plasma Biochemical Parameters, Weight of Organ

\section{Introduction}

Plantain is a main source of food in the world. African production is estimated to 26.545.032 tons in 2012 [1]. According to Frisson and Sharrock [2], plantain plays an important socio-economic role for developing countries in tropical and subtropical regions of Eastern, Central and West Africa, South East Asia, Central America and southern Caribbean. Plantain is a kind of energy food that provides $120 \mathrm{kcal}$ per $100 \mathrm{~g}$ of fruit, contributes to about $70 \%$ of the dietary energy supply [3]. Plantain is a major crop in Côte d'Ivoire with an annual production of 1.577.043 tons [1] and then set up the third rank of Ivorian food crop after yam and cassava [4]. About feeding, plantain is used to make various traditional dishes which the most important are foutou, fufu, aloco, akpessi, etc. [5,6].

Otherwise, plantain is a climacteric fruit. Ethylene production associated with absence of adequate structure of conservation accelerates the degradation of fruits and causing many losses estimated between 30 and $40 \%$ of the crop $[7,8]$.

Thus, women, to resolve their post-harvest losses, transform senescent plantain into a dish called Dockounou $[9,10]$. It is a traditional dish derived from the mixture of senescent plantain pulp with rice or maize flour which is boiled or baked [10,11]. A survey conducted by Akoa et al. [12] showed his good appreciation and wide consumption mainly from the urban. The studies of Kouadio et al. [13,14], have improved the nutritional value of boiled and baked Dockounou by using a mixture of senescent plantain dough with soybean flour in proportion 80:20 which had given the best performance in Wistar rats' growth. This proportion, in conservation objective, could be allowed to reduce post-harvest losses. The chemical studies conducted by Kra et al. [10] and Kouadio et al. [13] on these selected foods (boiled and baked soybean Dockounou) have shown that sugar and carbohydrate content are still high $(91.14 \mathrm{~g} / 100 \mathrm{~g}$ for boiled Dockounou and $94.38 \mathrm{~g} / 100 \mathrm{~g}$ for baked Dockounou) although proteins and lipids contents have been improved. However, it is known that excess sugar may bring many consequences for body. Indeed, Yudkin [15] had showed that two major carbohydrates, starch and sugars, were discussed and related to the epidemiology of coronary heart disease and diabetes. Also, Allen [16], had observed that sugars alter tissue expression of uncoupling proteins, create thus, many metabolic diseases such as diabetes, obesity, etc. and dysfunction of liver and kidney [17]. All these information suggests that, though soybean Dockounou had improved the Wistar rats' growth, it didn't guarantee the best state of health of these animals after consumption.

Indeed, Wistar rat is an indispensable tool in experimental medicine, nutritional science and drug development and has made inestimable contributions to human health [18]. It posed morphologic and physiologic organs which are the same rule as those of human $[19,20]$.

Thus, the aim of this study is to determine the health 
status of Wistar rat after being fed with boiled and baked Dockounou of soybean in 80:20 proportion.

\section{Materials and Methods}

\subsection{Sampling}

Fingers of senescent plantain (Musa paradisiaca) and grains of soybean (Glycine max) used in the production process were purchased from Adjame's market in Abidjan (Côte d'Ivoire).

\subsection{Obtention of Soybean Flour}

Soybean flour was obtained using the method described by Lombor et al. [21]. The soybean grains were sorted, cleaned and blanched at $100^{\circ} \mathrm{C}$ for $10 \mathrm{~min}$. Blanched grains were drained, dehulled and rinsed with $500 \mathrm{~mL}$ of water to remove the seed coat. Rinsed seed were then dried in oven at $80^{\circ} \mathrm{C}$ for $5 \mathrm{~h}$. Dried samples of soybean were separately milled and sieved with a $100 \mu \mathrm{m}$ particle size sieve.

\subsection{Formulation and Preparation of Soybean Dockounou}

The methods of Kra et al., Akoa et al. and Kouadio et al. $[10,22,23]$ were used for baked and boiled soybean Dockounou preparation. To be done, fruits of senescent plantain were washed, peeled and crushed in a traditional mortar for obtain a homogenous dough. This dough was fermented for 4 before being wrapped (at portion of $150 \mathrm{~g}$ ) in the leaves of Thaumatococcus danieilii. The dough wrapped was divided into two parts. One part was cooking in oven at $150^{\circ} \mathrm{C}$ for $1 \mathrm{~h}$ to obtain baked Dockounou and the other part was boiled in a saucepan with water at $100^{\circ} \mathrm{C}$ for $1 \mathrm{~h}$ to obtain boiled Dockounou. Proximate composition of boiled and baked soybean Dockounou is indicated in Table 1.

Table 1. Proximate composition of boiled and baked soybean Dockounou.

\begin{tabular}{|c|c|c|}
\hline Parameters & $\begin{array}{c}\text { Boiled soybean } \\
\text { Dockounou }\end{array}$ & $\begin{array}{c}\text { Baked soybean } \\
\text { Dockounou }\end{array}$ \\
\hline Moisture (\%) & 61.91 & 60.20 \\
\hline Dry matter (\%) & 38.10 & 39.80 \\
\hline Ash (\%) & 2.96 & 2.93 \\
\hline Acidity (meq/100 g) & 116.66 & 124.33 \\
\hline $\mathrm{pH}$ & 5.7 & 5.6 \\
\hline Lipids (\%) & 10.92 & 10.77 \\
\hline Total sugar (mg/100g) & 233.88 & 287.24 \\
\hline Proteins (\%) & 10.80 & 10.62 \\
\hline Carbohydrate (\%) & 13.39 & 15.46 \\
\hline Starch (\%) & 11.84 & 13.65 \\
\hline Calorific energy (kcal) & 165.66 & 171.34 \\
\hline
\end{tabular}

Source: [23]

\subsection{Feed of Rats}

The animal testing was done according to the method of Adrian et al. [24] recovery by Kouadio et al. [13,14]. Experiment was conducted with young Wistar rats from the animals' barn of the UFR Biosciences of Félix Houphouët-Boigny University (Abidjan, Côte d'Ivoire). The average temperature of the room was $26{ }^{\circ} \mathrm{C}$ and the percentage of humidity was $70 \%$, with 12 hours of daylight and 12 hours of darkness.

Three (3) groups of five (5) young Wistar rats each, with average initial weight varied from 55 to $60 \mathrm{~g}$ and $50 \pm 3$ day's age, were used. They were divided in such a way: one (1) group of five (5) young rats was submitted to control diets (C. diet) which to the SFACI society (Société de Fabrication d'Aliments Composés Ivoiriens) in Abidjan (Table 2), one (1) group of five (5) young rats were submitted to baked soybean Dockounou with the $80: 20$ formulation and one (1) other group of five (5) young rats were submitted to boiled soybean Dockounou with the same formulation.

The rats were acclimatized for three days during which they were fed with the control diet and thereafter fed with the different experimental diets. Rats were disposed in individual screened bottomed cages designed separately to feed ad libitum for fifteen (15) days.

Diets are distributed ad libitum once per day (between 6:00 to 7:00 am). Water was served at will and renewed every three days.

Table 2. Composition of control diet (granular from-(SFACI: Société de Fabrication d'Aliments Composés Ivoiriens).

\begin{tabular}{|c|c|}
\hline Components & Proportion \\
\hline Proteins & $15 \%$ \\
\hline Fat & $3.5 \%$ \\
\hline Cellulose & $12 \%$ \\
\hline Carbohydrate & $58 \%$ \\
\hline Minerals (calcium. phosphor. etc.) & $11.2 \%$ \\
\hline Vitamin A & $15000 \mathrm{UI} / \mathrm{Kg}$ \\
\hline Vitamin D3 & $3000 \mathrm{UI} / \mathrm{Kg}$ \\
\hline Vitamin E & $10 \mathrm{mg} / \mathrm{Kg}$ \\
\hline
\end{tabular}

\subsection{Collect of Blood Samples}

Blood collection is performed according to Weiss et al. [25] experimental protocol and modified by Descat [26]. The puncture of retro-orbital sinus of the animal was performed under anesthesia. This anesthetized was held with one hand in lateral recumbency and held by scruff of the neck. The pressure of the thumb on the neck behind the jaw angle allows a compression of the jugular veins venous stasis and therefore to the head favoring filling the retro-orbital sinus. By making a slight pull on the upper eyelid with the index, exophthalmia was created facilitating blood sampling by sterile Pasteur pipettes. The pipette tip 
was slowly introduced to the lateral angle of the eye. Progression through the tissue was facilitated by printing a slight rotation on the pipette. As soon as venous plexus reached, blood gushed out in the periorbital area and rose in the capillary pipette. Blood was collected in sterile haemolysis tube with a volume range from 0.5 to $2 \mathrm{~mL}$ according weight and age of the animal. Before withdrawal of the pipette, compression was released and the bleeding stopped spontaneously when the ocular pressure was normalized. The collected blood was stored immediately in a coolbox containing ice $\left(+2^{\circ} \mathrm{C}\right)$, before being sent to the Pasteur Institute laboratory (Cocody, Abidjan) for biochemical parameters analyses.

\subsubsection{Measurement of Serum Biochemical Parameters}

The blood was centrifuged at 3000 trs/min for $10 \mathrm{~min}$ and serum was collected into ependorfs tubes for biochemical parameters analyses using multiparametric controller Cobass C311 Hitachi. These parameters, built-in the automatic analyser, were tested according to the methods below: blood glucose was tested by glucose oxidase / peroxidase method of Trinder, Lott and Turner [27,28]; total proteins were evaluated according to Hiller et al. [29] and Spinreact [30] methods using the Biuret reagent; creatinine was evaluated according to the colorimetric method of Rasha and Ahmed [31] which is based on the reaction of creatinine with sodium picrate in alkaline medium; urea was evaluated according to Spinreact [32] method by enzymatic hydrolysis of urea into ammonia and carbon dioxide; total cholesterol was determinated by enzymatic-colorimetric assay of Trinder [27] using complex of cholesterol esterase, cholesterol oxidase and peroxidase; triglycerides were determinated using method described by [33-35] after enzymatic hydrolysis by lipases; HDL and LDL were detected directly in the serum by using cholesterol esterase and peroxidase according to the modified method of Young [36]; calcium and phosphorus were evaluated by using colorimetric assay, arsenazo III reagent mono of Budesinky [37] and Cadwel [38].

\subsection{Sampling of Animal Organs}

After the blood collection, the animals were sacrificed and a longitudinal laparotomy was performed in order to remove liver and both kidneys. The removed organs were dehumidified on clean toilet paper and then weighed on a Sartorius balance (precision: $0.001 \mathrm{~g}$ ).

\subsection{Statistical Analysis}

The statistical analysis of data was done by one way Analysis of Variance (ANOVA) using the software IBM SPSS Statistics version 20.0. Differences between means were tested using the Duncan Multiple Range Test with 5\% level of significance.

\section{Results}

Data in Table 3 presents biochemical parameters obtained for Wistar rats fed with boiled soybean Dockounou, baked soybean Dockounou and control diet. These results show that there is no significant difference $(\mathrm{P}>5 \%)$ between the plasma glycemia, total proteins, creatinine, cholesterol and triglycerides, calcium, phosphorus content of plasma and its ratio of $\mathrm{Ca} / \mathrm{P}$ for the rats fed with the three (3) diets. For glycemia, values were $0.80 \pm 0.06 \mathrm{~g} / \mathrm{L}, 0.74 \pm 0.13 \mathrm{~g} / \mathrm{L}$ and $0.74 \pm 0.11 \mathrm{~g} / \mathrm{L}$ for the control diet, boiled and baked soybean Dockounou, respectively. Total proteins of plasma values were $56.56 \pm 7.14 \mathrm{~g} / \mathrm{L}, 57.58 \pm 5.82 \mathrm{~g} / \mathrm{L}$ and $60.16 \pm$ $5.18 \mathrm{~g} / \mathrm{L}$, respectively. Creatinine contents were $2.6 \pm$ $0.89 \mathrm{~g} / \mathrm{L}, 3.2 \pm 0.44 \mathrm{~g} / \mathrm{L}$ and $3.2 \pm 0.44 \mathrm{~g} / \mathrm{L}$, respectively. Cholesterol contents were $0.93 \pm 0.06 \mathrm{~g} / \mathrm{L}, 2.91 \pm 0.16 \mathrm{~g} / \mathrm{L}$ and $0.86 \pm 0.15 \mathrm{~g} / \mathrm{L}$, respectively and for triglycerides, the values were $1.20 \pm 0.44 \mathrm{~g} / \mathrm{L}, 1.27 \pm 0.74 \mathrm{~g} / \mathrm{L}$ and $1.16 \pm$ $0.54 \mathrm{~g} / \mathrm{L}$ for the control diet, boiled and baked soybean Dockounou, respectively. Data obtained for calcium were $102.22 \pm 2.87 \mathrm{mg} / \mathrm{L}, 103.32 \pm 3.36 \mathrm{mg} / \mathrm{L}$ and $101.46 \pm$ $4.34 \mathrm{mg} / \mathrm{L}$ for the control diet, boiled and baked Dockounou, respectively. Phosphorus values measured were $75.44 \pm$ $6.56 \mathrm{mg} / \mathrm{L}, 78.76 \pm 5.40 \mathrm{mg} / \mathrm{L}$ and $79.00 \pm 7.21 \mathrm{mg} / \mathrm{L}$ for control diet, boiled and baked soybean Dockounou, respectively. The ratio $\mathrm{Ca} / \mathrm{P}$ data were $1.36 \pm 0.12,1.32 \pm$ 0.12 and $1.30 \pm 0.17$ for rats fed with control diet, boiled and baked soybean Dockounou, respectively.

Table 3. Biochemical parameters of Wistar rats fed with control diet, boiled and baked soybean Dockounou.

\begin{tabular}{|c|c|c|c|}
\hline Parameters & Control diet & $\begin{array}{c}\text { Boiled soybean } \\
\text { Dockounou }\end{array}$ & $\begin{array}{c}\text { Baked } \\
\text { soybean } \\
\text { Dockounou }\end{array}$ \\
\hline Glycemia (g/L) & $0.80 \pm 0.06^{\mathrm{a}}$ & $0.74 \pm 0.13^{\mathrm{a}}$ & $0.74 \pm 0.11^{\mathrm{a}}$ \\
\hline $\begin{array}{c}\text { Total proteins } \\
(\mathrm{g} / \mathrm{L})\end{array}$ & $56.56 \pm 7.14^{\mathrm{a}}$ & $57.58 \pm 5.82^{\mathrm{a}}$ & $60.16 \pm 5.18^{\mathrm{a}}$ \\
\hline Urea $(\mathrm{g} / \mathrm{L})$ & $0.41 \pm 0.10^{\mathrm{b}}$ & $0.56 \pm 0.17^{\mathrm{ab}}$ & $0.67 \pm 0.12^{\mathrm{a}}$ \\
\hline Creatinine (g/L) & $2.6 \pm 0.89^{\mathrm{a}}$ & $3.2 \pm 0.44^{\mathrm{a}}$ & $3.2 \pm 0.44^{\mathrm{a}}$ \\
\hline $\begin{array}{c}\text { Cholesterol } \\
(\mathrm{g} / \mathrm{L})\end{array}$ & $0.93 \pm 0.06^{\mathrm{a}}$ & $0.91 \pm 0.16^{\mathrm{a}}$ & $0.86 \pm 0.15^{\mathrm{a}}$ \\
\hline $\begin{array}{c}\text { Triglycerides } \\
(\mathrm{g} / \mathrm{L})\end{array}$ & $1.20 \pm 0.44^{\mathrm{a}}$ & $1.27 \pm 0.74^{\mathrm{a}}$ & $1.16 \pm 0.54^{\mathrm{a}}$ \\
\hline HDL $(\mathrm{g} / \mathrm{L})$ & $0.55 \pm 0.02^{\mathrm{b}}$ & $0.65 \pm 0.069^{\mathrm{a}}$ & $0.62 \pm 0.05^{\mathrm{a}}$ \\
\hline LDL (g/L) & $0.31 \pm 0.05^{\mathrm{a}}$ & $0.16 \pm 0.04^{\mathrm{b}}$ & $0.17 \pm 0.05^{\mathrm{b}}$ \\
\hline $\begin{array}{c}\text { Calcium (mg/L) } \\
102.22\end{array}$ & $103.32 \pm 3.36^{\mathrm{a}}$ & $101.46 \pm 4.34^{\mathrm{a}}$ \\
\hline $\begin{array}{c}\text { Phosphor } \\
(\mathrm{mg} / \mathrm{L})\end{array}$ & $75.44 \pm 6.56^{\mathrm{a}}$ & $78.76 \pm 5.40^{\mathrm{a}}$ & $79.00 \pm 7.21^{\mathrm{a}}$ \\
\hline Ratio Ca/P & $1.36 \pm 0.12^{\mathrm{a}}$ & $1.32 \pm 0.12^{\mathrm{a}}$ & $1.30 \pm 0.17^{\mathrm{a}}$ \\
\hline
\end{tabular}

On the other hand, there is a significant difference between urea, HDL and LDL according diet at $\mathrm{P}>5 \%$. For urea, values obtained were higher for rats fed with baked soybean Dockounou $(0.67 \pm 0.12 \mathrm{~g} / \mathrm{L})$ than boiled soybean Dockounou $(0.56 \pm 0.17 \mathrm{~g} / \mathrm{L})$ and control diet $(0.41$ $\pm 0.10 \mathrm{~g} / \mathrm{L})$. Those for HDL were higher for rats fed with boiled Dockounou $(0.65 \pm 0.06 \mathrm{~g} / \mathrm{L})$ and baked Dockounou 
$(0.62 \pm 0.05 \mathrm{~g} / \mathrm{L})$ than those of control diet $(0.55 \pm 0.02 \mathrm{~g} / \mathrm{L})$. Concerning LDL content, registered value are higher for control diet $(0.31 \pm 0.05 \mathrm{~g} / \mathrm{L})$ than boiled Dockounou $(0.16$ $\pm 0.04 \mathrm{~g} / \mathrm{L})$ and baked Dockounou $(0.17 \pm 0.05 \mathrm{~g} / \mathrm{L})$.

Table 4 presents biometric values of rats fed with control diet, boiled and baked soybean Dockounou. The results show that, there is no significant difference $(\mathrm{P}>5 \%)$ between the liver weights of rats fed with the three (3) diets. These values were $3.70 \pm 0.45 \%, 3.51 \pm 0.51 \%$ and 3.13 $\pm 0.51 \%$ for control diet, boiled and baked soybean Dockounou, respectively. Concerning the kidney, results were statistically different at $5 \%$ level. The kidney weights of rats fed with baked soybean Dockounou were higher than these of rats fed with boiled soybean Dockounou and control diet. The weight varied from $0.77 \pm 0.07 \%$ to $0.90 \pm$ $0.07 \%$ for control diet and baked soybean Dockounou, respectively.

Table 4. Organs weight of rats fed with control diet, boiled and baked soybean Dockounou.

\begin{tabular}{|c|c|c|c|}
\hline Diets & Control diet & $\begin{array}{c}\text { Boiled soybean } \\
\text { Dockounou }\end{array}$ & $\begin{array}{c}\text { Baked soybean } \\
\text { Dockounou }\end{array}$ \\
\hline Liver & $3.70 \pm 0.45^{\mathbf{a}}$ & $3.51 \pm 0.51^{\mathbf{a}}$ & $3.13 \pm 0.51^{\mathbf{a}}$ \\
\hline Kidney & $0.77 \pm 0.07^{\mathbf{b}}$ & $0.85 \pm 0.07^{\text {ab }}$ & $0.90 \pm 0.07^{\mathbf{a}}$ \\
\hline
\end{tabular}

Values are mean \pm standard deviation of triplicate determinations. Values with different superscripts are significantly different from each other at the $5 \%$ level $(\mathrm{P}>0.05)$ on the same line. $P$-value $=3.53$

Values are mean \pm standard deviation of triplicate determinations. Values with different superscripts are significantly different from each other at the 5\% level (P > 0.05 ) on the same line. $P$-value $=0.28$

\section{Discussion}

\subsection{Biochemical Parameters Studies}

The biochemical parameters represent the substances of body concentrations are relatively constant and their degree of variation could reveal the functional status of organism [39-42]. Thus, the increase or decrease in production of a metabolite could due to a malfunction in the organs such as kidney and liver that regulate the functioning of these metabolites [43].

The glycemia or rate of blood glucose was an important parameter which allows detecting some diseases such as diabetes. It is the fact that cells don't receive glucose and most of them are accumulated in blood. Thus, too much sugar in blood can lead to serious health problems, including heart disease and damage to the nerves and kidneys $[44,45]$. The glycemia values of Wistar rats and Guinea pig were located in the reference range of 0.5 $1.35 \mathrm{~g} / \mathrm{L}$ and $0.6-1.25 \mathrm{~g} / \mathrm{L}[46,47]$. According to the results, there are no significant difference $(\mathrm{P}>5 \%)$ in glycemia contents of rats fed with control diet and these for rats fed with boiled and baked soybean Dockounou. These rates are between the values reported by [46]. The results showed that soybean Dockounou consumption does not increase blood sugar of the animals and doesn't affect negatively the functioning of liver and kidney which regulated the metabolism of blood sugar in rats.

Concerning the proteins of serum, it exerts a beneficial effect such as the maintenance of the osmotic pressure, the transport of molecules, the plasma purifying, strengthening the immune system and blood coagulation [30]. According to Rerat [48], the rate of serum proteins depends on the proteins content of the diet and can contribute to increase the rate of urea and creatinine in serum [49]. The high proteins diet exerts a chronic effect by inducing hypertrophy of nephron [50] on the one hand and the low proteins of diet can provoke malnutrition on the other hand. The values obtained in our study $(57.58 \pm 5.82$ and $60.16 \pm$ 5.18 for boiled and baked soybean Dockounou, respectively) were included in to $56-76 \mathrm{~g} / \mathrm{L}$ the reference range of Wistar rats [46] and these of Guinea pig (46 - 62g/L) [47]. The lack of significant difference between the rats fed with control diet and those fed with boiled and baked soybean Dockounou shows that the consumption of Dockounou does not influence negatively the content of serum in proteins during the diet experimental period.

For urea, there is a significant difference between the various batches of rats. Urea is a product of proteins metabolism synthetized by the liver, and is therefore removed from the blood by the kidneys. It is freely filters through the glomerulus, but is reabsorbed by the renal tubules in a flow dependent fashion. The higher flow rate, the greater amount of urea nitrogen are cleared from circulation and eliminated through the kidneys. As a result, the level of circulating of urea nitrogen serves as a primary measure of kidney function [51]. The values registered $(0.56 \pm 0.17 \mathrm{~g} / \mathrm{L}$ and $0.67 \pm 0.12 \mathrm{~g} / \mathrm{L}$ for boiled and baked Dockounou, respectively) were, in one hand, higher than reference range of Wistar rat $(0.15-0.21 \mathrm{~g} / \mathrm{L})$ [46] and Guinea pig $(0.09-0.315 \mathrm{~g} / \mathrm{L})$ [47] and, the other part, lower than reference range of rabbit $(6.18-7.35 \mathrm{~g} / \mathrm{L})$ [52]. The increase of plasma urea content could be explained by catabolism of excess of serum proteins and by dehydration due to the observed fasting prior to blood collection [31]. Indeed, the young rats were in a phase of growth which demanded a strong metabolic activity. This period needs more proteins metabolism to help with the rat growth.

Concerning creatinine, it's a metabolite which results from the converting in serum of creatine produced in the cells by organs such as the brain and muscle for growth, tissue repair and other energy dependent activities [53-55]. It is released into the blood stream and freely filtered, and excreted by the kidneys. The serum creatinine level is commonly used as an indicator of kidney function. It permits to estimate the rate of glomerular filtration of kidney which is important for elimination of creatinine content [51]. The results obtained for creatinine in this 
study $(3.2 \pm 0.44 \mathrm{~g} / \mathrm{L}$ and $3.2 \pm 0.44 \mathrm{~g} / \mathrm{L}$ for boiled and baked Dockounou, respectively) were higher than those reported for Wistar rats $(0.002-0.008 \mathrm{~g} / \mathrm{L})$ by [46] and for guinea pig $(0.006-0.0022 \mathrm{~g} / \mathrm{L})$ by Roger [47]. This high content of creatinine could be explained by the high increase of muscular mass and body weight of young rats' link to the type of diet (good content of proteins due to the soybean), their mainly physical activities and also by dehydration due to the observed fasting prior to blood collection which affects glomerular filtration [43]. The fact that there is no significant difference in creatinine content for rats fed with soybean Dockounou and control diet shows that this metabolite would well regulated by rats' kidney.

The serum rate of cholesterol and triglycerides of young rats fed with control diet and experimental diets didn't show any significant difference at $\mathrm{P}>5 \%$. Cholesterol and triglycerides are both fatty substances found in blood, bile and brain tissue. They serve as a precursor to bile acids, steroids and vitamin D. The concentrations of total cholesterol and triglycerides in serum have been associated with metabolic and coronary disease such as diabetes mellitus, nephrosis, biliary obstruction and various metabolic abnormalities due to endocrine disturbances $[56,57]$. Cholesterols contents are in accordance with the reference range of Wistar rat which is between 0.40 to $1.30 \mathrm{~g} / \mathrm{L}[46]$. Thus, the values obtained for rats fed with boiled and baked soybean Dockounou suggested a good liver function for these substances. Therefore, consumption of soybean Dockounou does not induce diseases such as diabetes, obesity and cardiovascular disease for rats. These facts revealed the good health condition of the rats fed with boiled and baked soybean Dockounou.

About HDL and LDL levels, the results show a high content of HDL and low content of LDL in blood of rats fed with boiled and baked soybean Dockounou in comparison to rats fed with control diet. The HDL and LDL values obtained are comparable to those reported by Goutianos et al. [58] which are respectively about $0.55 \mathrm{~g} / \mathrm{L}$ and $0.15 \mathrm{~g} / \mathrm{L}$ for Wistar rats. In fact, Lipoprotein LDL and HDL are different effects on coronary heart disease risk. While HDL has a protective effect, LDL is the key factor of pathogenesis of all atherosclerosis and coronary disease $[59,60]$. Thus, low HDL levels are strongly associated with an increased risk of coronary disease, heart disease and coronary artery disease $[61,62]$. Desirable levels of HDL concentration are considered to be a higher value of $40 \mathrm{mg} / \mathrm{dL}$. The desirable levels of LDL concentration are considered below $77.3 \mathrm{mg} / \mathrm{dL}$. The high content of HDL shows that soybean Dockounou consumption could protect the body against cardiovascular diseases following an increase in HDL cholesterol. Consequence would be the induction of risk reduced of blood clots in the coronary arteries (vessels supplying the heart), a phenomenon responsible for cardiac infarction [63].

Calcium and phosphorus contents and the ratio of calcium / phosphorus of serum didn't show any significant difference $(\mathrm{P}>5 \%)$ among rats batches subjected to different diets. Phosphorus is essential in formation and the maintenance of the health of bones and teeth. It takes part in the growth, regeneration of tissue and maintains to normal $\mathrm{pH}$ of blood. Also, calcium intervenes in the formation of bones and teeth. It plays an important role in blood coagulation, maintenance of blood pressure, regulation of body $\mathrm{pH}$ and contraction of muscles [64]. Excessive phosphorus intakes elevate serum phosphorus levels and disturb the hormonal regulation of calcium which may result in decreasing of bone strength and an increasing risk of fractures [65]. Also, the deleterious effects of excessive phosphorus intake on bone increase when calcium intake is low [66]. Therefore, adequate dietary calcium intake is needed to overcome the harmful effects of a high phosphorus intake on bone health [67]. Thus, Sherman [68] recommends a ratio of calcium / phosphorus between 1 and $2 \mathrm{~g} / \mathrm{L}$ for rapid growth and good calcification of bones. The fact that $\mathrm{Ca} / \mathrm{P}$ ratio values obtained $(1.32 \pm 0.12 \mathrm{~g} / \mathrm{L}$ and $1.30 \pm 0.17 \mathrm{~g} / \mathrm{L}$ for boiled and baked soybean Dockounou, respectively) are between this range shows that the consumption of boiled and baked soybean Dockounou exerts a good influence in the constitution of rats' serum in bone's formation. Otherwise, excess calcium intake provokes a kidney stones and a likely increase of a cardiovascular risk $[69,70]$.

\subsection{Biometric Parameters}

Liver and kidney are organs involved in the metabolism of nutrients. Liver provides three vital functions such as purification function (elimination of cholesterol, transformation of ammonia in urea, etc.), synthesis function (coagulation factors synthesis and cholesterol synthesis, etc.) and a storage function while kidney intervenes in the regulation of blood pressure, elimination of toxins (with liver and lung) and maintain, by filtration and excretion of urine, the hydroelectric balance (homeostasis) of blood. Thus, changing in the weight of these organs constitutes a way to explore them indirectly in nutrition according studies of [24].

The results of parameters measured, showed that there is no significantly difference $(\mathrm{P}>5 \%)$ in relative organ weight of liver for rats fed with control diet and those fed with soybean Dockounou. Thus, Dockounou consumption has not induced a change in the weight of this organ. In fact, Greaves, Amacher et al. and Juberg et al. [71-73] considered that alterations in liver weight may suggest treatment-related changes including hepatocellular hypertrophy (e.g., enzyme induction or peroxisome proliferation). These values are similar to those obtained by Amoikon et al. [74] with rats fed by fish (3.27\%) and fish associated to chromium tripicolinate (3.31\%). These results demonstrated a healthy liver function of rats fed with soybean Dockounou.

By cons in kidney, it appeared an increase of the relative 
weight for rats fed with soybean Dockounou. The changes in kidney weight may reflect the rate of glomerular filtration of kidney which is important for elimination of urea, creatinine and other metabolize substances produced [51]. Also, the stress condition, due to dehydration, can explain the increase of kidney weight reflected by hypertrophy which results either from an increase in the mechanical or metabolic activity of the cell or an increased hormonal stimulation [71,75]. Thereby, according to Werner and Inga et al. [76,77] normal renal size varies according to the body habitus. Also, the variation can be expressed as a function of body weight and height. Furthermore, these authors are reported that there is a correlation between kidney size and body weight at birth and at adulthood. All these facts revealed that the kidney of rats are well functioned and exert a strong metabolic activity.

\section{Conclusions}

The biochemical parameters measured in the plasma of rats fed with boiled and baked soybean Dockounou and their organs (liver and kidney) exploration are not revealed abnormality or malfunctions in these various metabolic parameters and organs which were studied. It can therefore be concluded that the consumption of this food does not induced metabolic diseases. Moreover, the young rats' liver and kidney functioning had revealed a high metabolic activity after feeding them with the cooked foods. Thus, the rats ate compatible food to their organism which provided them the necessary nutrients for their development that this food can be advised for feeding the laboratory wistar rats.

\section{REFERENCES}

[1] FAOSTAT. Organisation des Nations Unies pour l'Alimentation et l'Agriculture, Département Économique et Social. La Division de la Statistique; http://faostat.fao.org., 2012.

[2] E.A. Frisson, S. Sharrock. The economic, social and nutritional importance of banana in the world. In: Pic. C. Fouré E. and Frisson E.A. eds. Bananas and food security, International symposium, Douala. Cameroun. Montpellier. France: INIBAP., 21-35, 1998.

[3] H.T. Emaga, A.R. Herinavalona, B. Wathelet, T. Tchango, M. Paquot. Effects of the stage of maturation and varieties on the chemical composition of banana and plantain peels. Food Chem., Vol.103, 590-600, 2007.

[4] H. Du Croquet. L'agriculture Ivoirienne à la loupe (1). Le professionnel agricole, Vol.3, 10-12, 2002.

[5] A. Lassoudière. Le bananier plantain en Côte d'Ivoire. Fruits, $28: 453-462,1973$.

[6] N.G. Agbo, M. Coulibaly. Recensement des techniques traditionnelles de conservation de la banane plantain en Côte
d'Ivoire. Projet CRDI n 3-A-87- 4994 - Rapport final. 52 p, 1989.

[7] M.J-L. Rodríguez, S.A. Rodríguez, C.S. Belalcázar. Importancia Socioeconómica del Cultivo del Plátano en la Zona Central Cafetera (Segunda Versión) Oficina Regional de Planeación - Corpoica. Regional Nueve. Manizales, 1999.

[8] H.T. Emaga, B. Wathelet, M. Paquot. Changements texturaux et biochimiques des fruits du bananier au cours de la maturation. Leur influence sur la préservation de la qualité du fruit et la maitrise de la maturation. Biotechnologie, Agronomie, Société et Environnement, Vol.12, 89-98, 2008.

[9] F.G. Honfo, A. Tenkouano, O. Coulibaly. Banana plantain-based foods consumption by children and mothers in Cameroon and Southern Nigeria: A comparative study. Afr. J. Food Sci., Vol.5, 287-291, 2001.

[10] K.A.S. Kra, E.E. Akoa, R-M. Megnanou, K. Yeboue, E.E. Akpa, L.S. Niamke. Physicochemical and nutritional characteristics assessment of two different traditional foods prepared with senescent plantain. Afr. J. Food Sci., Vol.7, 51-55, 2013.

[11] E.E.F. Akoa, R-M. Megnanou, K.A.S. Kra, L.S. Ahonzo-Niamke. Technical variation in the processing of dockounou: a traditional plantain derivate dish of Côte d'Ivoire. Ame. J. Resea. Com., 1, 81-97, 2013.

[12] E.E.F. Akoa, K.A.S Kra, R-M. Megnanou, L.S. Ahonzo-Niamke. Sensorial characteristics of a senescent plantain empiric dish (Dockounou) produced in Côte d'Ivoire. J. Food Resea., Vol.1, No.4, 150-159, 2012.

[13] N.J. Kouadio, M. Rose-Monde, A. Eric, E.A. Edwige, K.K. Séverin, L.N. Sébastien. Impact of the nutritional supply of Dockounou with millet. soybean. cassava. sorghum flours in Wistar rat growth. Int. J. Inn. App. Stu., Vol.10, 576-583, 2015.

[14] N.J. Kouadio, A-Y.G. Koua, M. Cissé, K.A.S. Kra, L.S. Niamké. Nutritional status of baked dockounou formulated with senescent plantain and six sell flours. Int. J. Food Nutr. Sci., Vol.5, No.4, 11-26, 2015.

[15] Yudkin J. Metabolic changes induced by sugar in relation to coronary heart disease and diabetes. Nutr. Health., Vol.5, 5-8, 1987.

[16] Allen S. Sugars and Fats: the neurobiology of preference. J. Nutr., Vol.133, 831S-834S, 2003.

[17] Appleton. Lick the Sugar Habit- Avery Penguin Putnam, Nancy. New York; enzymes, 1988.

[18] R.A. Gibbs, G.M. Weinstock, M.L. Metzkerl, et al. Genome sequence of the Brown Norway rat yields insights into mammalian evolution: Rat Genome Sequencing Project Consortium. Nature Publishing Group, Vol.428, 493-521, 2004.

[19] W.S. Bivin, M.P. Crawford, N.R. Brewer. Morphophysiology. In: the laboratory rat, biology and diseases (H.J. Baker, J.R. Lindsey, S.H. Weisbroth, eds.). Academic Press, New York, Vol.1, 73-103, 1979.

[20] J.R. Olds. A color atlas of the rat, dissection guide. John Wiley \& Sons, New York, NY, ISBN: 0470266473, 1979.

[21] T.T. Lombor, E.J. Umoh, E. Olakumi. Proximate composition 
and organoleptic properties of complementary food formulated from millet (Pennisetum psychostchynum), soybeans (Glycine max) and crayfish (Euastacusspp). Pak. J. Nut., Vol.8, 1676-1679, 2009.

[22] E.E.F. Akoa, K.A.S. Kra, R-M. Mégnanou, N.J. Kouadio, L.S. Niamké. Optimization of dockounou manufacturing process parameters. Sust. Agr. Res., Vol.3, 67-75, 2014.

[23] N.J. Kouadio, E.E.F. Akoa, K.A.S. Kra, L.S. Niamké. Enrichment of senescent plantain dish with local cereal and leguminous flours for feeding rats: growth performance evaluation. In press. 2016.

[24] J. Adrian, M. Rabache, R. Fragne. Technique d'analyse nutritionnelle. In : Lavoisier Tec et Doc (Eds) Paris. Principes de techniques d'analyse, 451-478, 1991.

[25] J. Weiss, G.R. Taylor, F. Zimmermann, K. Nebendahl. The laboratory Rat Collection of body fluids- In: KRINKE.GJ. The handbook of experimental Animal-Academic press Vol.25, 485-495, 2000.

[26] F. Descat. Hématologie du rat: hémogramme et myélogramme. Thèse médecine vétérinaire, Toulouse, 109 p, 2002.

[27] P. Trinder. Determination of blood glucose using 4 amino phenazone as oxygen acceptor. J. Clinic Pathol., Vol.22, 246-255, 1960.

[28] J.A. Lott, K. Turner. Evaluation of Trinder's Glucose Oxidase Method for Measuring Glucose in Serum and Urine. Clin. Chem., Vol.21: 1754-1760, 1975.

[29] A. Hiller, J. Plazin, D.D. Van Slyke. A study of conditions for Kjeldahl determination of nitrogen in proteins; description of methods with mercury as catalyst, and titrimetric and gasometric measurements of the ammonia formed. J. Biol. Chem., Vol.176, No.3, 1401-1420, 1948.

[30] Spinreact. Total protein Biuret. Colorimetric; Quantitative determination of total protein. SPINREACT, S.A./S.A.U. Ctra.Santa Coloma, 7 E-17176 SANT ESTEVE DE BAS (GI) Espagne. 2015.

[31] M. Rasha, M. Ahmed. Formulation of Reduced Calorie and Trans-free Fat Biscuits Using Palm Oil and Sucralose: Study of Their Hypoglycemic Activity on Albino Rats. Ame. J. Food Nutr., Vol.3, No.6, 131-140. 2015.

[32] Spinreact. UREA - B. Berthelot. Enzymatique colorimétrique. Détermination quantitative d'urée. SPINREACT, S.A./S.A.U. Ctra.Santa Coloma, 7 E-17176 SANT ESTEVE DE BAS (GI) Espagne, 2015.

[33] N.W. Tietz. Clinical Guide to Laboratory Tests, Second Edition W.B. Saunders Company, Philadelphia, USA, 554-556, 1990.

[34] N.J. Jacobs and P.J. Van Demark. The purification and properties of the alpha-glycerophosphate-oxidizing enzyme of Streptococcus faecalis 10C1. Arch. Bioch. Biophys., Vol.88, 250-255, 1960.

[35] L.K. Koditschek, W.W. Umbreit. $\alpha$-Glycerophosphate Oxidase in Streptococcus faecium F 24. J. Bacte., Vol.98, No.5, 1063-1068, 1969.

[36] D.S. Young. Effects of Drugs on Clinical Laboratory Tests, 3rd ed., AACC Press, Washington DC, 3-104 thru 3-106, 1990.
[37] Budesinky B. Chelñates. In: Analytical Chemistry., Vol.18, 5067-5073, 1969.

[38] P.C. Cadwell. Calcium chelation and buffers In Calcium and Cellular Function. Ed. Cuthbert A.W., Macmillan, London, 10-16, 1970.

[39] J. Borel, J. Caron, J. Chanard, L. Gougeon, M. Leutenegger, F.X. Maquart, G. Potron, A. Randoux, P. Zeitoun. Comment prescrire et interpréter un examen de biochimie. 2ème éd. Paris: Maloine, 15-36, 1984.

[40] R. Jurcik, K. Suvegova, E. Hanusova, P. Massanyi, L. Ryban, P. Chrenek. Evaluation of haematological, biochemical and histopathological parameters of transgenic rabbits. J. Vet. Med. Series A, Vol.54, No.9, 527-531, 2007.

[41] A. Melillo. Rabbit clinical pathology. J. Exot. Pet. Med. Vol.16, 135-145, 2007.

[42] J.R. Jenkins. Rabbit diagnostic testing. J. Exot. Pet. Med., Vol.17, 4-15, 2008.

[43] K.G.M. Bouafou. Etude de la production d'asticots à partir d'ordures ménagères et de la valeur nutritionnelle de la farine d'asticots séchés (FAS) chez le rat en croissance. Thèse de Doctorat Physiologie Animale de l'Université de Cocody, Abidjan, Côte d'Ivoire, p. 145, 2007.

[44] D. Hofso, T. Jenssen, J. Bollerslev, J. Roislien, H. Hager, J. Hjelmesaeth. Anthropometric characteristics and type 2 diabetes in extremely obese Caucasian subjects: a cross-sectional study. Diabet Resea. Clin. Pract., Vol.86, 9-11, 2009.

[45] J.E. Gerich. Review Article: Role of the kidney in normal glucose homeostasis and in the hyperglycaemia of diabetes mellitus: therapeutic implications. Diabet Med., Vol.27, 136$142,2010$.

[46] C. Johnson-Delaney. Exotic Companion Medicine Handbook for Veterinarians (2 Vol. Set). Lake Worth, FL: Zoological Education Network, 500p, 1996.

[47] J. Roger. The aging process in the guinea-pig. J. Geron., Vol.16, 13-16, 1951.

[48] A. Rérat. Valeur biologique des protéines: quelques acquisitions récentes. Ann. Zootech., Vol.20, 193 - 246, 1971.

[49] B. Backlund, D.L. Zoran, M.B. Nabity, B. Norby, J.E. Bauer. Effects of dietary protein content on renal parameters in normal cats. J. Feline Med. Surgery, Vol.13, 698-704 2011.

[50] R.F. Delmar. Effects of Dietary Protein Intake on Renal Functions, Nurtrition and Renal Function in Cats and Dogs, Vol.21, No. 11(K), 5-10, 1999.

[51] A.C. Storm, L. Naing, N.L. Htike, D.A. Cohen, L. Robert, R.L. Benz. A Surviving Patient with Record High Creatinine. Open J. Nephr., Vol.3, 217-219, 2013.

[52] C. Özkan, A. Kaya, Y. Akgül. Normal values of haematological and some biochemical parameters in serum and urine of New Zealand White rabbits. World Rabbit Sci., Vol.20, 253-259, 2012.

[53] R.W. Hamilton, L.B. Gardner, A.S. Penn, M. Goldberg. Acute tubular necrosis caused by exercise-induced myoglobinuria. Ann. Int. Med., Vol.77, No.1, 77-82, 1972. 
[54] N.V. Bhagavan. Protein and Amino Acid Metabolism, In: J. Hayhurst, Ed., Medical Biochemistry, Harcourt/ Academic Press, Burlington, 331-332, 2002.

[55] J.M. Watras. Berne \& Levy Physiology, 6th Edition. Mosy, Inc., Santa Clara, 246-247, 2008.

[56] G. Buccolo, D. Harold. Quantitative determination of serum triglycérides by use of enzymes. Clin. Chem., Vol.19, No.5, 476-482, 1973

[57] H.K. Naito. Kaplan A et al. In Cholesterol. The C.V.Mosby Co. St Louis. Toronto, Princeton. Clin. Chem., Vol.437, 1194 1206, 1984.

[58] Goutianos G, Tzioura A, Kyparos A, Paschalis V, Margaritelis NV, Veskoukis AS, Zafeiridis A, Dipla K, Nikolaidis MG, Vrabas IS The rat adequately reflects human responses to exercise in blood biochemical profile: a comparative study. Physiol. Rep., Vol.3, 1-9, 2015.

[59] W.B. Kannel, W.P. Castelli, T. Gordon. Cholesterol in the prediction of atherosclerotic disease; New perspectives based on the Framingham study. Ann. Int. Med., Vol.90 No.1, 85-91, 1979.

[60] J.R. Crouse, J.S. Parks, H.M. Schey, F.R. Kahl. Studies of low density lipoprotein molecular weight in human beings with coronary artery disease. J. Lipid Resea., Vol.26, No.5, 566-574, 1985.

[61] W.P. Castelli, J.T. Doyle, T. Gordon, C.G. Hames, M.C. Hjortland, S.B. Hulley, A. Kagan, W.J. Zukel. HDL Cholesterol and other lipids in Coronary Heart Disease, The cooperative lipoprotein phenotyping study. Circulation, Vol.55, No.5: 767-772, 1977.

[62] NIH (National Institute of Health). Lowering blood cholesterol to prevent heart disease. Rev. Nutr., Vol.43, 283-285, 1985.

[63] M.E. Brousseau, E.J. Schaefer. Diet and coronary heart disease: clinical trials. Curr. Atheroscler. Rep., Vol.2, 487- 493, 2000.

[64] A.L. Boskey. Mineralization, structure, and function of bone. In Dynamics of Bone and Cartilage Metabolism: Principles and Clinical Applications. 2nd edition. Edited by Seibel MJ, Robins SP, Bilezikian JP. San Diego. Academic Press, 201209. 2006

[65] G. Vicente-Rodriguez, J. Ezquerra, M.I. Mesana, J.M. Fernández-Alvira, J.P. Rey-López, J.A. Casajus, A.M. Luis. Independent and combined effect of nutrition and exercise on bone mass development. J. Bone Miner. Metab., Vol.26, 416424, 2008.

[66] M.S. Calvo. The effects of high phosphorus intake on calcium homeostasis. Adv. Nutr. Research., Vol.9, 183-207, 1994.

[67] E. Takeda, H. Yamamoto, H. Yamanaka-Okumura, Y. Taketani. Increasing dietary phosphorus intake from food additives: potential for negative impact on bone health. Adv. Nutr., Vol.5, 92-97, 2014.

[68] H.C. Sherman. Chemistry of Food and Nutrition. The Macmillan Co., New York N. Y., 272p, 1946.

[69] S.R. Williams. Essentials of Nutrition and Diet Therapy (6th edn). Masson: New York, 1994.

[70] M.G. Brunette. Régulation du métabolisme calcique. In Désordres Acido-basiques et Hydroélectrolytiques, Offenstadt G, Brunette MG (eds). Arnette Blackwell: Paris, 294-312, 1997.

[71] P. Greaves. Histopathology of Preclinical Toxicity Studies: Interpretation and Relevance in Drug Safety Evaluation, 4th edition. Elsevier Science, Amsterdam. ISBN: 9780444538611, 2011.

[72] D.E. Amacher, S.J. Schomaker, S.E. Boldt, M. Mirsky. The relationship among microsomal enzyme induction, liver weight and histological change In cynomolgus monkey toxicology studies. Food Chem. Toxicol., Vol.44, No4, 52837,2006

[73] D.R. Juberg, D.R. Mudra, G.A. Hazelton, A. Parkinson. The effect of fenbuconazole on cell proliferation and enzyme induction in the liver of female CD1 mice. Toxicol. Appl. Pharm., Vol.214, No.2, 178 - 87, 2006.

[74] K.E. Amoikon, K.G. Kouame, S. Kati-Coulibaly. Effect of chromium and proteins diets in rats. Int. J. Plant Ani. Env. Sci., Vol.2, No.2, 1-8, 2012.

[75] R.S. Sellers, D. Morton, M. Bindhu, N. Roome, J.K. Johnson, L. Barry, R.P. Yano, K. Schafer. Organ Weight recommendations for Toxicology Studies. Tox. Patho., Vol.35:751-755; 2007.

[76] S.H. Werner Normal variance in renal size in relation to body habitus. SA J. Radiology, Vol.15 No.4 123-126, (2011).

[77] J.M. Inga, M. Rita, R.G. Indra. The relationship between nephron number, kidney a size and body weight in two inbred mouse strains. Organogenesis, Vol.6, No.3, 189-194, 2010. 